\title{
Mechanisms of action of systemic antibiotics used in periodontal treatment and mechanisms of bacterial resistance to these drugs
}

Geisla Mary Silva SOARES ${ }^{1}$, Luciene Cristina FIGUEIREDO², Marcelo FAVERI², Sheila Cavalca CORTELLI ${ }^{3}$, Poliana Mendes DUARTE², Magda FERES ${ }^{4}$

1- DDS, MSc, PhD student, Department of Periodontology, Dental Research Division, Guarulhos University, Guarulhos, $\mathrm{SP}$, Brazil.

2- DDS, MSc, PhD, Professor, Department of Periodontology, Dental Research Division, Guarulhos University, Guarulhos, $\mathrm{SP}$, Brazil.

3- DDS, MSc, PhD, Professor, Department of Periodontology and Preventive Dentistry, Dental Research Division, University of Taubaté, Taubaté, SP, Brazil.

4- DDS, MSc, DMSc, Professor and Chair, Department of Periodontology, Dental Research Division, Guarulhos University, Guarulhos, SP, Brazil.

Corresponding address: Magda Feres - Centro de Pós-Graduação e Pesquisa-CEPPE - Universidade Guarulhos Praça Tereza Cristina, 229 - Centro - 07023-070 - Guarulhos - SP - Brazil - e-mail: mferes@ung.br

Received: September 21, 2010 - Modification: August 16, 2011 - Accepted: September 20, 2011

\section{ABSTRACT}

\begin{abstract}
$\Delta$ ntibiotics are important adjuncts in the treatment of infectious diseases, including Aperiodontitis. The most severe criticisms to the indiscriminate use of these drugs are their side effects and, especially, the development of bacterial resistance. The knowledge of the biological mechanisms involved with the antibiotic usage would help the medical and dental communities to overcome these two problems. Therefore, the aim of this manuscript was to review the mechanisms of action of the antibiotics most commonly used in the periodontal treatment (i.e. penicillin, tetracycline, macrolide and metronidazole) and the main mechanisms of bacterial resistance to these drugs. Antimicrobial resistance can be classified into three groups: intrinsic, mutational and acquired. Penicillin, tetracycline and erythromycin are broad-spectrum drugs, effective against gram-positive and gram-negative microorganisms. Bacterial resistance to penicillin may occur due to diminished permeability of the bacterial cell to the antibiotic; alteration of the penicillin-binding proteins, or production of $\beta$-lactamases. However, a very small proportion of the subgingival microbiota is resistant to penicillins. Bacteria become resistant to tetracyclines or macrolides by limiting their access to the cell, by altering the ribosome in order to prevent effective binding of the drug, or by producing tetracycline/macrolide-inactivating enzymes. Periodontal pathogens may become resistant to these drugs. Finally, metronidazole can be considered a prodrug in the sense that it requires metabolic activation by strict anaerobe microorganisms. Acquired resistance to this drug has rarely been reported. Due to these low rates of resistance and to its high activity against the gram-negative anaerobic bacterial species, metronidazole is a promising drug for treating periodontal infections.
\end{abstract}

Key words: Antibiotics. Drug resistance. Periodontal diseases. Infectious diseases. 


\section{INTRODUCTION}

Antimicrobial agents are substances produced by various species of microorganisms (bacteria, fungi, actinomycetes) that suppress the growth of other microorganisms and may eventually destroy them. However, common usage often extends the term "antibiotics" to include synthetic or semisynthetic antibacterial agents, such as sulfonamides and metronidazole, which are not produced by microbes. The modern era of antimicrobial therapy started with the clinical use of sulfonamide in 1936. The "golden age" of antibiotics began with the production of penicillin in 1941, when this compound, discovered by Alexander Fleming in 1928, was finally mass-produced and first made available for limited clinical trials ${ }^{18}$. The remarkable success of penicillin in treating bacterial infections quickly diverted a great deal of scientific effort towards the search for other antibiotics. Different laboratories initiated an intensive search for antibiotics produced by moulds isolated from soil samples from all parts of the world and further successes quickly followed. Since then, hundreds of antibiotics have been identified, and many have been developed to the stage where they are of value in the therapy of numerous infections, including periodontal diseases.

Microbial resistance is a natural biological response of microbes to a selective pressure, such as weather conditions, food, oxygen or water availability, or the presence of an antimicrobial drug. When a new class of antibiotic is introduced, it is effective at first, but will eventually select for survival of the small fraction of bacterial populations that have an intrinsic or acquired resistance mechanism ${ }^{166}$. However, there is a scarcity of information on the susceptibility to antibiotics of bacterial species isolated from patients with periodontitis, since microbial sensitivity tests are not normally performed in daily practice either in dentistry or in medicine, especially in countries where there is high antibiotic consumption ${ }^{86}$. This habit has contributed to the emergence of multidrug-resistant strains of both Gram-negative (Pseudomonas, Klebsiella, Salmonella) and Gram-positive (Staphylococcus, Enterococcus, Streptococcus) species and has become a public health problem ${ }^{135}$.

The commensal microbiota of the oral cavity can act as a reservoir of antibiotic-resistant microorganisms, some of which are capable of causing local and systemic diseases. Data from the literature suggest that antibiotic resistance in the periodontal microbiota has increased ${ }^{163}$. The knowledge of the biological mechanisms involved with antibiotic usage as well as of the results of well conducted randomized clinical trials would help dental professionals prescribing these drugs only when their real efficacy for the treatment of a certain infection has been proved. This is the most effective way of avoiding the development of resistance. Therefore, the aim of this manuscript was to review the mechanisms of action of the antibiotics most commonly used in the periodontal treatment (i.e. penicillin, tetracycline, macrolide and metronidazole), and the main mechanisms of bacterial resistance to these drugs.

\section{MECHANISM OF ACTION AND RESISTANCE}

\section{I- General considerations}

One of the results of the widespread use of antibiotics has been the emergence of antibioticresistant pathogens, a phenomenon that constitutes a threat to the successful treatment of infectious diseases. To understand the mechanisms of resistance it is important to remind that antibiotics are classified based on their mechanism of action, as follows:

Agents that inhibit synthesis of bacterial cell walls (e.g. penicillins and cephalosporins);

Agents that interfere with the cell membrane of the microorganism, affecting permeability ( e.g. some antifungal agents);

Agents that inhibit protein synthesis by affecting the function of $30 \mathrm{~S}$ or $50 \mathrm{~S}$ ribosomal subunits (e.g. tetracyclines, macrolides and clindamycin);

Agents that block important metabolic steps of the microorganisms (e.g. sulfonamides and trimethoprim);

Agents that interfere with nucleic acid synthesis (e.g. metronidazole and quinolones).

Antimicrobial resistance can be classified into 3 groups: intrinsic, mutational and acquired resistance. Intrinsic resistance refers to an inherent resistance to an antibiotic that is a naturally occurring feature of the microorganism. For example, certain oral bacteria such as many streptococci lack the nitroreductases necessary to convert metronidazole to its active metabolites and therefore are not affected by the drug ${ }^{163}$. Mutational resistance occurs due to a spontaneous chromosomal mutation that produces a genetically-altered bacterial population that is resistant to the drug. Mutations resulting from the change of a single nucleotide base can result in resistance, as has been well documented for aminoglycosides and for rifampin ${ }^{163}$. Finally, acquired resistance refers to the horizontal acquisition from another microorganism of a genetic element that encodes antibiotic resistance. This process can occur by transduction, transformation or conjugation. Transduction is a process by which exogenous DNA is transferred from one bacterium to another by the intervention of a bacteriophage, 
while transformation is the process by which bacteria acquire segments of DNA that are free in the environment. In conjugation the passage of genetic material occurs by direct cell-to-cell contact, through a sex pilus or bridge. This is the most common mechanism of transferring antibiotic resistance genes.

In general, bacteria use 3 main strategies to become resistant to different antibiotics: (a) preventing the drug from reaching its target ${ }^{100,101}$, (b) altering the target ${ }^{62,145}$, and (c) inactivating the antibiotic 28,124 .

\section{II- Penicillins}

Penicillins, together with the cephalosporins, are the major $\beta$-lactam antibiotics. In 1928, while studying staphylococcus variants, Alexander Fleming observed that a mold contaminating one of his cultures caused the lyses of adjacent bacteria. Because the mold belonged to genus Penicillium, Fleming named the antibacterial substance penicillin. More than a decade later, in 1941, enough purified penicillin had been produced to conduct therapeutic trials in several patients desperately ill with staphylococcal and streptococcal infections and the results were exceptional. Since then, many other antimicrobial agents have been developed but the penicillins are still one of the most important groups of antibiotics and new derivatives of the basic penicillin nucleus are still being produced.

The basic structure of the penicillins consists of a thiazolidine ring connected to a $\beta$-lactam ring, to which is attached an acyl side chain. The first penicillin introduced, penicillin $G$, is the only natural penicillin currently used clinically. The first semi synthetic derivative, penicillin $V$, was found to be more stable than penicillin $\mathrm{G}$ following oral administration. However, both drugs have limited activity against Gram-negative bacteria and are readily hydrolyzed by bacterial-produced hydrolyzing enzymes, $\beta$-lactamases. Later, further modifications and substitutions of the acyl side chain, led to the production of other semi synthetic penicillins with enhanced antimicrobial properties. Such properties included activity against Gramnegative as well as Gram-positive bacteria with a narrow spectrum of activity directed against specific bacteria, increased stability in oral and stomach acids and increased absorption, resulting in lower dosages necessary to establish therapeutic levels ${ }^{164}$.

The penicillins as well as other $\beta$-lactam antibiotics are bactericidal drugs. They kill susceptible bacterial by inhibiting the synthesis of the bacterial peptidoglycan cell wall ${ }^{144,169}$. The peptidoglycan provides the cell with rigid stability due to its highly cross-linked structure and its synthesis has 3 stages. The first and second stages take place in the cytoplasm. Initially, there is amino sugar linkage followed by the addition of specific amino acids (L-alanine, D-glutamic acid, L-lysine, followed by a dipeptide, D-alanyl$D$-alanine) in a prescribed order to form uridine diphosphate (UDP)-acetylmuramyl-pentapeptide. The final stage occurs outside the cell to complete the cross-link, when new subunits are added to the growing peptidoglycan. The terminal glycine residue of the pentaglycine bridge is linked to the fourth residue of the pentapeptide ( $D$-alanine), releasing the fifth residue (also D-alanine) ${ }^{87}$. The penicillins and cephalosporins interfere with this last step in peptidoglycan synthesis by acting as an analog of the D-alanine-D-alanine portion of the $\mathrm{N}$-acetyl muramic moiety. The conformation of penicillin is very similar to that of $\mathrm{D}$-alanine-D-alanine, so the enzymes involved in the transpeptidation reaction react with the $\beta$-lactam nucleus, inactivating the transpeptidase reaction and results in the formation of new peptidoglycan chains that are not crosslinked and lack tensile strength. Weak points develop in the growing cell wall, which result in cell rupture due to osmotic lysis ${ }^{169}$. In addition, there are more targets for the actions of penicillins, which are collectively termed penicillin-binding proteins $(\mathrm{PBP})^{143}$, structures that all bacteria possess.

Resistance to penicillin may occur due to any of the 3 mechanisms described in the introduction section:

a) Preventing the drug from reaching its target: diminished permeability of the bacterial cell to the antibiotic;

b) Altering the target: alteration(s) of the penicillin-binding proteins;

c) Inactivating the antibiotic: bacterial production of inactivating enzymes, referred to as $\beta$-lactamases.

\section{IIa- Diminished permeability of the bacterial cell to the antibiotic}

This type of resistance is only observed in Gram-negative organisms due to differences found in the structure and composition of Gram-positive and Gram-negative cell wall. In Gram-positive bacteria the peptydoglycan polymer is very close to the cell surface, allowing the antibiotic to easily penetrate the cell. The situation is different with Gram-negative bacteria, since they contain an outer membrane consisting of lipopolysaccharide that acts as a barrier to hydrophobic compounds in general, and to hydrophilic compounds that exceed a certain molecular weight. The outer membrane functions as an impenetrable barrier to some antibiotics ${ }^{98}$. However, some small, hydrophilic antibiotics diffuse through aqueous channels in the outer membrane formed by proteins called porins. This is the primary reason for the difference in susceptibility of Gram-negative and Gram-positive bacteria to 
hydrophobic antibiotics such as certain penicillins. Broader spectrum penicillins, such as ampicillin and amoxicillin, diffuse through the porin pores of Gram-negative bacteria significantly more rapidly than penicillin $\mathrm{G}$. The number and size of pores in the outer membrane are variable among different Gram-negative bacteria. For example, Haemophilus influenzae is thought to be much more susceptible to $\beta$-lactam antibiotics than Escherichia coli due to the presence of larger porin channels ${ }^{156}$. Specific mutations of gene(s) coding for the porin proteins can impair the entry of hydrophobic penicillins into the cell and result in an increase in the minimal inhibitory concentration of the antibiotic for the organism $^{163}$.

\section{IIb-Alteration(s) of the penicillin-binding proteins}

Microorganisms may be intrinsically resistant to penicillin because of structural difference in the PBPs that are the targets of this drug. It is also possible that a sensitive strain acquires resistance of this type by altering the PBP affinity to $\beta$-lactam antibiotics, as observed in methicillin-resistant staphylococci ${ }^{48}$ and in penicillin-resistant gonococcal strains ${ }^{60}$. It has also been reported that the highlevel of resistance of Streptococcus pneumoniae to $\beta$-lactam antibiotics is mediated by successive alterations in essential PBPs. These low affinity PBPs may be a result to an acquired mutation or bee due to interspecies gene transfer ${ }^{54}$.

\section{IIC- Bacterial production of $\beta$-lactamases}

The most important mechanism of resistance to penicillins and cephalosporins is $\beta$-lactamase mediated hydrolysis of the $\beta$-lactam ring, resulting in inactivation of the antibiotic. These enzymes are often referred to as penicillinase or cephalosporinase, depending on the drug on which they act. However, some enzymes demonstrate activity against both classes of antibiotics. In general, Gram-positive bacteria produce a large amount of $\beta$-lactamase, which is secreted extracellularly. Therefore, in a mixed bacterial population, such as the subgingival microbiota of a periodontal pocket, the production of $\beta$-lactamase by relatively few Gram-positive bacteria may protect other bacteria that would normally be susceptible to penicillins. In Gram-negative bacteria, $\beta$-lactamases are found in relatively small amounts and are located in the periplasmic space, between the inner and outer cell membranes. Since the enzymes of cell-wall synthesis are on the outer surface membrane, these $\beta$-lactamases are strategically located for maximal protection of the microbe. Therefore, the production of a relatively small amount of $\beta$-lactamase that is retained within the outer membrane of Gram-negative bacteria is often sufficient to keep the internal concentration of the antibiotic below inhibitory levels. $\beta$-lactamases can be either chromosomal or plasmid encoded, and they may be constitutive or inducible.

\section{IId-Resistance of oral species}

A very small proportion of the subgingival microbiota is resistant to penicillins ${ }^{69,114,150}$. Suter, et al. ${ }^{150}$ (1983) reported that among 193 assorted oral isolates, only $2 \%$ were resistant to penicillin G at a concentration of $2 \mathrm{U} / \mathrm{mL}$. Kinder, et al. ${ }^{69}$ (1986) also showed that less than $3 \%$ of the subgingival microorganisms associated with adult periodontitis were resistant to penicillin. The predominant resistant subgingival isolates recovered in this investigation consisted of Bacteroides, Veillonella, Haemophilus, Eikenella, Capnocytophaga, and Streptococcus species ${ }^{73,149,150}$. The main mechanism of resistance to $\beta$-lactam antibiotics in the oral cavity seems to be the production of $\beta$-lactamase. This enzyme is frequently detected in diseased periodontal sites and appears to be positively correlated with increased periodontal pocket depth $^{165}$. $\beta$-lactamases have been detected in dark-pigmented Prevotella species, Haemophilus and Capnocytophaga species in patients with adult periodontitis ${ }^{70}$. Van Winkelhoff, et al. ${ }^{161}$ (1997) determined the occurrence of $\beta$-lactamase producing periodontal bacteria in 23 untreated adult periodontitis patients. Of the selected putative periodontal species, strains of Prevotella intermedia, Fusobacterium nucleatum and to the first time, Tannerella forsythia, were $\beta$-lactamase positive, with $P$. intermedia being the most frequently detected enzyme positive species. Feres, et al. ${ }^{36}$ (2002) analyzed the microbiota in 20 subjects with chronic periodontitis assigned to receive orally administered amoxicillin at the dosage of $500 \mathrm{mg}$, T.I.D. for 14 days. In order to determine the antibiotic resistance, subgingival plaque samples were taken from six posterior teeth at baseline and at 90 days; and from two randomly selected teeth at 3, 7 and 14 days during and after antibiotic administration. The most prevalent resistant species were $S$. constellatus, Prevotella nigrescens, Eubacterium saburreum, Actinomyces naes/undii $1, S$. oralis, Prevotella melaninogenica and $P$. intermedia; however, the mean percentage of resistant isolates increased during antibiotic administration and returned to baseline levels by 90 days post-therapy. Handal, et al. ${ }^{55}$ (2004) demonstrated a wide variety and a high prevalence ( $72 \%$ ) of $\beta$-lactamase-producing bacteria that may play a role in refractory periodontal disease. Species belonged to genus Prevotella and other anaerobic strains such as $F$. nucleatum, Capnocytophaga spp. and Neisseria sp. were also detected among these enzyme producers.

The prevalence of $\beta$-lactamase producers 
seems to increase with age. Nyfors, et al. ${ }^{103}$ (2003) selected healthy 2-month-old infants for a 22-month longitudinal study. They found a prevalence of $F$. nucleatum of $2 \%$ and $49 \%$ at baseline and the end of the study, respectively. Most of the $\beta$-lactamaseproducing isolates ( $80 \%)$ were clearly resistant to penicillin G. Also, among 35 children (4-5 years old), Ready, et al. ${ }^{114}$ (2003) found many strains of the genus Veillonella, traditionally susceptible to penicillin and ampicillin, resistant to both antimicrobials.

Inhibitors of $\beta$-lactamase such as clavulanic acid can be combined with amoxicillin, for instance, resulting in a $\beta$-lactamase resistant drug concentration ${ }^{53,88}$. This combination has shown beneficial effects on the treatment of chronic and refractory periodontitis from 10 months to 3 years post-treatment ${ }^{26,49,50,88}$. Chan and Chan ${ }^{19}$ (2003) assessed 178 bacterial strains isolated from 74 patients (9-72 years old) with pyogenic infections of odontogenic origin. When comparing the bactericidal activity, amoxicillin/clavulanate was more effective than amoxicillin alone in susceptible strains of $P$. intermedia, P. micra and Eikenella corrodens. Both the $\mathrm{MIC}_{50}$ and $\mathrm{MIC}_{90}$ of amoxicillin/ clavulanate were 2 to 4 times lower than those of amoxicillin and ampicillin, respectively, but there were some strains of $E$. corrodens $(8,4 \%), F$. nucleatum $(11,4 \%)$ and $P$. micra $(11,1 \%)$ that were resistant to amoxicillin/clavulanate.

In addition to periodontal pathogens, opportunistic or superinfectant microorganism have also been detected in oral samples as Enterococcus faecalis and Staphylococcus aureus. E. faecalis were identified in $11 \%$ of oral rinses from endodontic patients and all strains were susceptible to ampicillin ${ }^{131}$. Loberto, et al. ${ }^{83}$ (2004) isolated Staphylococcus aureus from $4.55 \%$ of the subgingival samples of 88 patients with chronic periodontitis. Bernardo, et al. ${ }^{9}$ (2005) reported a high percentage $(79.5 \%)$ of $S$. aureus resistant to ampicillin in the dental clinic environment, which may represent a risk to patients if crosscontamination occurs. As mentioned before, a resistant bacterial species may transfer the resistance genes to other oral bacterial species, especially in a biofilm environment.

\section{III- Tetracyclines}

After intensive screening of soil specimens collected from many parts of the world for antibiotic producing organisms, the first tetracycline, chlortetracycline was introduced in $1948^{68}$. Subsequently, thousands of related compounds have been examined, a few of which have been developed for clinical use to treat infectious diseases.

Although there are specific differences between the currently available tetracyclines, they are sufficiently similar to allow them to be discussed as a group. They are broad-spectrum antibiotics effective against aerobic and anaerobic Gram-positive and Gram-negative bacteria as well as Richettsia, Mycoplasma, Chlamydia spp. and Legionella spp. They consist of 4 fused cyclic rings, hence the name tratracyclines. The various derivatives have only minor alterations of the chemical constituents attached to this basic ring structure ${ }^{164}$. The most commonly used are tetracycline hydrochloride, doxycycline and minocycline. All three have a similar spectrum of activity, and resistance to one may indicate resistance to all three. Tetracyclines are bacteriostatic agents at clinically achieved concentrations $^{130}$. They inhibit bacterial protein synthesis by binding to the $30 \mathrm{~S}$ bacterial ribosome and preventing access of aminoacyl tRNA to the acceptor $(A)$ site on the mRNA-ribosome complex ${ }^{90,148}$. This interrupts the formation of the initiation complex required for amino acid protein synthesis ${ }^{29}$. Tetracyclines can also cause alterations in the cytoplasmic membrane leading to leakage of nucleotides and other compounds from the bacterial cell ${ }^{109}$. At higher concentrations, tetracycline may inhibit protein synthesis in mammalian cells. However, mammalian cells lack the active transport system found in bacteria that pump tetracyclines through the inner cytoplasmic membrane. Furthermore, differences in sensitivity at the ribosomal level are important determinants of the selective action of these drugs ${ }^{68}$. Doxycycline and minocycline are semi-synthetic derivatives of tetracycline. These two compounds are more lipid soluble which gives them some advantages over tetracycline hydrochloride, such as a lower dosage regimen, prolonged serum half-life, super tissuefluid penetration and decreased gastrointestinal side-effects ${ }^{8,21}$. In addition to the antimicrobial effect, tetracyclines are capable of inhibiting collagenase ${ }^{40}$. This inhibition may interfere with tissue breakdown in periodontal disease. Furthermore they bind to tooth surfaces, from which they may be released slowly over time ${ }^{146}$. Bacteria use 3 strategies to become resistant to tetracycline: ${ }^{41,118,142 \text { : }}$

a) Preventing the drug from reaching its target: limiting the access of tetracycline to the ribosomes;

b) Altering the target: altering the ribosome to prevent effective binding of tetracycline;

c) Inactivating the antibiotic: producing tetracycline-inactivating enzymes.

IIIa. Limiting tetracycline access to the ribosome

Reduced uptake

For tetracycline to inhibit protein synthesis, it must enter the bacterial cell and bind to the 
ribosome. Some Gram-negative bacteria limit the diffusion of tetracycline into the periplasm by altering the porin proteins (e.g. OmpF) present in the cell wall. This type of resistance, which can decrease susceptibility 6- to 18 - fold, has been found in a number of Gram-negative bacteria24,25,128. Cohen, et al. ${ }^{25}$ (1988) have shown that the multiple antibiotic resistances of some $E$. coli strains are due not only to change in OmpF but also to changes in other outer membrane proteins.

\section{Tetracycline efflux}

A second way of limiting the access of tetracycline to ribosomes is to reduce intracellular concentrations of tetracycline by pumping the antibiotic out of the cell at a rate equal to or greater than its uptake ${ }^{142}$. This resistance mechanism, tetracycline efflux, is the best-studied and most familiar mechanism of bacterial resistance ${ }^{91}$. Two major groups of efflux systems are known, specific exporters and transporters conferring multidrug resistance. The genes of multidrug resistance systems are commonly located on the bacterial chromosome. In contrast, the genes coding for specific efflux systems are often associated with mobile genetic elements which can easily be interchanged between bacteria $^{15}$. The resistance gene product is a cytoplasmic membrane protein that is an energydependent tetracycline transporter. To date, many classes of tetracycline efflux genes have been identified. $\operatorname{tet}(\mathrm{A})$ to tet $(\mathrm{E})$ were found among the members of the family of Enterobacteriaeceae and the genera Haemophilus, Vibrio, Aeromonas, and Moraxella ${ }^{80,122}$. tet $(\mathrm{P})$, has been found in Clostridium $\mathrm{spp}^{1}$ and tet(K) and $(\mathrm{L})$ were detected in Grampositive bacteria11,61,92. $\operatorname{tet}(\mathrm{G}),(\mathrm{H}),(\mathrm{V})$ and otrA were identified and also specify active efflux of tetracycline $32,33,56,118$. In 2000, Tauch, et al. ${ }^{153}$ (1979) propose a new class of tetracycline resistance and repressor proteins, termed $\operatorname{Tet} A(Z)$ and $\operatorname{Tet} R(Z)$. Furthermore, proteins of the TetR family have been found in 115 genera of Gram-positive, alpha, beta and gamma-proteobacteria, cyanobacteria and archaea $^{113}$.

Efflux pumps can be considered potentially effective antibacterial targets. Inhibition of efflux pumps by an efflux pump inhibitor would restore the activity of an agent subject to efflux ${ }^{81}$. Moreover, according to Kaatz ${ }^{67}$ (2005) the identification of broad-spectrum efflux pump inhibitors may reduce the need to discover and develop new antimicrobial agents that are not pump substrates.

\section{IIIb- Ribosome protection}

This is a less familiar type of tetracycline resistance mechanism than the efflux type. Burdett, in $1986^{14}$, was the first to show that the ribosomes of resistant cells were in fact less sensitive to tetracycline than those of sensitive cells in an in vitro translation system. Although this mechanism is less familiar, it is probably more widespread than tetracycline efflux ${ }^{126}$. The resistance gene product is a cytoplasmic protein that interacts or associates with the ribosome, making it insensitive to tetracycline ${ }^{13,14}$. In 1991, Burdett ${ }^{13}$ purified one of the ribosome protection resistance proteins (Tet $(M)$ ) and showed that it could bind the ribosomes. Some classes of the ribosome protection resistance genes have been characterized and sequenced: $\operatorname{tet}(\mathrm{M})$, tet( $\mathrm{O})$, tet( $\mathrm{Q})$ and $\operatorname{tet}(\mathrm{S})^{20,78,102,126}$. Tet(O) and $\operatorname{Tet}(\mathrm{M})$ (75\% sequence similarity) are soluble cytoplasmic proteins located on mobile genetic elements ${ }^{27}$. Tet(M) has been found in a wide variety of bacteria, including Streptococcus, Neisseria, Haemophilus, Mycoplasma, Bacteroides and Staphylococcus ${ }^{31,66,99}$. Tet(O), originally found in Campylobacter spp., has also been found in Streptococcus, Enterococcus, Lactobacillus and Mobiluncus spp. ${ }^{119,171}$ while tet(Q) has been found in Bacteroides and Prevotella species ${ }^{75,102,107,108}$. Finally, during a investigation of anaerobic bacteria present in swine feces and manure storage pits Whittle, et al. ${ }^{167}$ (2003) isolated a new Bacteroides strain (Bacteroides sp. Strain 139) that contained a previously unidentified tetracycline resistance gene designated Tet(36).

\section{IIIc- Tetracycline inactivation}

The third type of tetracycline resistance mechanism is the enzymatic inactivation of the drug. This type of resistance was discovered by accident when Guiney, et al. ${ }^{47}$ (1989) were attempting to clone a tetracycline resistance gene from the obligate anaerobe Bacteroides fragilis. They cloned a gene that conferred tetracycline resistance on $E$. coli, but it did not confer resistance on the Bacteroides. This resistance gene has been classified as tet( $X)$ and the gene product is a cytoplasmic protein that chemically modifies tetracycline in a reaction that requires oxygen ${ }^{142}$. The clinical significance of $\operatorname{tet}(X)$ is unclear. Not only does it not confer resistance to the Bacteroides strains in which it was originally found, but it requires such high levels of aeration to function as a resistance factor in $E$. coli that it probably could not confer meaningful levels of resistance in the microaerophilic environment found in most sites of the human body ${ }^{142}$.

\section{IIId- Resistance of oral species}

Resistance to tetracycline in periodontal pathogens has been observed. Fiehn and Westergaard $^{37}$ (1990) examined the presence of doxycycline resistant bacteria in subgingival plaque of 12 periodontally healthy and 12 periodontally 
diseased subjects. At baseline, the occurrence of bacteria resistant to $10 \mu \mathrm{g} / \mathrm{mL}$ of doxycycline was around $4 \%$ in the healthy group and $1 \%$ in the diseased group. The periodontally diseased subjects received conventional therapy supplemented by doxycycline at the dosage of $100 \mathrm{mg} /$ day for 20 days. The percentage of resistant bacteria increased from $1 \%$ to $18 \%$ within 1 week after starting the therapy. However, this change was transient, as about 6 months after therapy the values returned to baseline. A similar study was carried out by Olsvik, et al. ${ }^{106}$ (1995) in a group of patients with refractory periodontal disease. Bacterial isolates resistant to $10 \mu \mathrm{g} / \mathrm{mL}$ of tetracycline were isolated from plaque samples of 17 patients, of whom 6 had received tetracycline within 8 weeks prior to sampling. In these 6 patients, a mean of $22.9 \%$ of the total cultivable subgingival microbiota was resistant to tetracycline, compared with a mean of $7.2 \%$ in the untreated group. Although various organisms were isolated, in the majority of patients, the tetracycline-resistant organisms were dominated by Streptococcus spp. Magnusson, et al. ${ }^{89}$ (1991) compared the patterns of susceptibility to 6 antimicrobial agents of whole plaque samples from 18 patients with refractory periodontitis and 10 patients with chronic periodontitis. The isolates from the group with refractory periodontitis showed a tendency to higher levels of antimicrobial resistance to a variety of drugs. This difference was significant for tetracycline and for doxycycline at $4 \mu \mathrm{g} / \mathrm{ml}$. Chan and Chan $^{19}$ (2003) assessed 178 bacterial strains isolated from 74 patients (9-72 years old) with pyogenic infections of odontogenic origin. Tetracycline exhibited poor activity against the oral pathogenic bacteria. Conversely, the new tetracycline derivates, minocycline and doxycycline with a breakpoint of $8 \mu \mathrm{l} / \mathrm{mL}$, expresses very pronounced antimicrobial activity and could inhibit over $95 \%$ of the isolated species, including $P$. gingivalis, E. corrodens, $P$. intermedia, $F$. nucleatum and $P$. micra, at a MIC $^{90}$.

Abu Fanas, et al. ${ }^{2}$ (1991) reported an increase in the MIC values of tetracycline for subgingival isolates of $P$. gingivalis, $P$. intermedia and $F$. nucleatum in a group of subjects that received 250 mg tetracycline 4 times daily for 2 weeks. There is evidence that long-term use tetracycline favors the selection or development of resistant strains in periodontal pockets ${ }^{72,168}$. Kornman and Karl ${ }^{72}$ (1982) evaluated 10 patients with periodontal disease who had been taking $250 \mathrm{mg}$ of tetracycline daily for 2-7 years. They reported that up to $77 \%$ of the cultivable subgingival microbiota was resistant to tetracycline at $1 \mu \mathrm{g} / \mathrm{ml}$ and Gram-negative rods constituted $58 \%$ of the microbiota. Another 10 patients who had received the same treatment were examined 6 months after discontinuing the long- term antibiotic therapy and the resistant species dropped to $26 \%$. In the same study, 14 untreated control subjects had a mean of $7 \%$ resistant isolates. Goodson and Tanner ${ }^{42}$ (1992) studied the antibiotic resistance of the subgingival microbiota in tetracycline fiber-treated periodontal sites. No Gram-negative rods resistant to tetracycline at 16 $\mu \mathrm{g} / \mathrm{mL}$ were observed six months after patients received the local treatment. Intermediate levels of tetracycline resistance before and after the fiber therapy were observed for E. corrodens, Campylobacter gracilis, P. oris. Capnocytophaga gingivalis and Selenomonas sp. In no case was resistance higher after therapy than before.

Rodrigues, et al.125 (2004) longitudinally evaluated the tetracycline resistance patterns of the subgingival microbiota of periodontitis subjects treated with systemic or local antibiotic plus scaling and root planing (SRP). The predominant tetracycline-resistant species included $P$. intermedia, Veillonela parvula, $P$. micra and $A$. actinomycetemcomitans ${ }^{6,30}$. The percentage of resistant microorganisms increased significantly in a time interval of 1 week in the tetracycline groups, but dropped to baseline levels over time. The authors concluded that local or systemically administered tetracyclines result in only a transitory selection of subgingival species intrinsically resistant to this drug.

Van Winkelhoff, et al.158 (2000) investigated antimicrobial resistance of the subgingival microbiota of untreated patients with chronic periodontitis in the Netherlands and Spain. The percentage of resistant strains of most periodontal pathogens was higher among Spanish patients. In Spain, 5 patients had at least 3 tetracycline resistant periodontal pathogens, whereas this was not observed in any of the Dutch patients.

Resistance to tetracycline among oral microorganisms has also been examined at the genetic level. The tet $(\mathrm{M})$ determinant is commonly found in some subgingival species considered "beneficial" such as oral streptococci, Veillonella and Actinomyces spp. ${ }^{74,104,105,121}$. Lacroix and Walker ${ }^{74}$ (1995) subcultured and identified 204 tetracyclineresistant strains from 68 patients with chronic periodontitis. Tet(M) was detected in $60 \%$ of the isolates. The tet $(\mathrm{M})$ containing strains consisted mainly of streptococci (55\%, mostly S. intermedius, S. oralis, S. sanguinis), Actinomyces spp. (14\%), Bifidobacterium spp. (11\%) and Veillonella spp. (10\%).

Of the periodontal pathogens, several strains of $F$. nucleatum have been shown to harbor the tet(M) determinant in a conjugal transposon ${ }^{120}$. More recently Olsvik, et al. ${ }^{105}$ (1995), using the polymerase chain reaction (PCR), reported the presence of the tet(M) gene in one isolate of $E$. saburreum and in 
two isolates of Gemella morbillorum. A 519-basepair fragment of the tet( $\mathrm{O})$ gene was also amplified from 13 streptococcal isolates.

The $\operatorname{tet}(\mathrm{Q})$ determinant confers resistance to tetracycline only in Gram-negative rods ${ }^{74,107,108}$. The gene was first detected in intestinal Bacteroides species $^{47,137}$ but a closely related determinant has been found in some oral Prevotella species ${ }^{46,107}$. Afterwards, Olsvik, et al. ${ }^{104}$ (1996) and Lacroix and Walker ${ }^{75}$ (1996) encountered the tet(Q) gene in tetracycline resistant Prevotella isolates from periodontally diseased patients, including $P$. intermedia and $P$. nigrescens.

Villideu, et al. ${ }^{162}$ (2003) screened saliva and plaque samples of 20 healthy adults for the presence of bacteria resistant to tetracycline presenting tetracycline resistance genes. The most common tet gene identified was tet(M), followed by tet $(\mathrm{W})$, tet $(0)$ and $\operatorname{tet}(\mathrm{Q})$. The authors reported, for the first time, the isolation of tet(W) gene from the oral cavity. This gene was present in genus Veillonella, Prevotella, Spreptococcus, Staphylococcus, Lactobacillus and Neisseria. Kim, et al. ${ }^{69}$ (2011) analyzed resistance determinants in oral biofilm samples associated with periodontal health or disease. Interestingly, the levels of tet( $Q)$, tet $(\mathrm{M})$, and ermF were higher in samples from the periodontitis than from the periodontally healthy group. The authors emphasize that this may occur because some of these resistant genes are more common in Gram-negative bacteria, which are found in higher levels in subjects with periodontitis. This situation may hinder successful periodontal treatment by tetracycline due to increased antibiotic resistance.

\section{IV- Macrolide}

The first described macrolide was erythromycin that has been available for clinical use for about 40 years. Azithromycin and clarithromycin are semi-synthetic macrolides similar in structure to erythromycin. Azithromycin is a member of a new subclass of macrolide, the azalides ${ }^{12}$ and differs from erythromycin by the addition of a methyl-substituted nitrogen atom into the lactone ring. This change produces a compound that is more acid stable and has a longer serum half-life, increased tissue penetration, and greater activity against gram-negative organisms compared with erythromycin ${ }^{59,172}$. All the macrolide related compounds are available for oral use and clarithromycin is also available as an intravenous infusion. Erythromycin is effective against grampositive bacteria and spirochetes, but not against most gram-negative organisms. It is often used as an alternative to penicillin for those patients who are allergic to this antibiotic. All macrolides are well absorbed from the gastro-intestinal tract and diffuse readily into most tissues. Erythromycin is inactivated in the liver, whereas clarithromycin is converted into an active metabolite. The major route of elimination for macrolides is via the bile ${ }^{134}$.

The macrolides, lincosamides and streptogramin B class of antibiotics target bacterial ribosomes ${ }^{134}$. Although there is general agreement that macrolidelincosamide-streptogramin antibiotics inhibit protein synthesis by binding to ribosomes, the actual mechanism has only recently been explained. It has been suggested that macrolide antibiotics, which consist of a 12- to 16-membered lactone ring replaced with one or more sugars, inhibit protein synthesis by two different mechanisms depending on their structure, blocking elongation of the nascent polypeptide by binding to the opening of the ribosomal exit tunnel causing a drop-off event leading to the accumulation of toxic peptidyltransfer RNA ${ }^{110}$.

Three mechanisms of resistance to macrolides have been described, comprising:

a) Preventing the drug from reaching its target: limiting the access of macrolides to the cells (efflux pumps);

b) Altering the target: altering the ribosome to prevent effective binding of macrolides;

c) Inactivating the antibiotic: bacterial production of inactivating enzymes.

\section{IVa- Efflux}

Distinct efflux genes have been described. The expression of genes in the MEF family may also be associated with low-level macrolide resistance in the bacteria of the oral microbiota, encoding another efflux pump $p^{7,71}$. Efflux by an ATP-binding transporter encoded by msrA was found in $S$. aureus ${ }^{117}$. In gram-negative bacteria the pumps are frequently of the RND variety, and in gram-positive bacteria, both the major facilitator super family (MFS) and the $A B C$ transporter super families are found ${ }^{79,123}$.

\section{IVb- Target modification}

Target modification can be due to the acquisition of one of $21 \mathrm{erm}$ genes. These codes for rRNA methylases bring about methylation of adenine residues in $23 \mathrm{~S}$ rRNA, preventing the binding of macrolides to the $50 \mathrm{~S}$ ribosomal subunit. The more common ribosomal modification however, is mutation of nucleotide 2058 again, which resides in the macrolide binding pocket of the $23 \mathrm{~S}$ ribosomal RNA. In eubacteria this is invariably adenine and a point mutation resulting in a guanine at this position interferes with macrolide binding 151,170 .

\section{IVc- Antibiotic modification}

There have been reports of a variety of enzymes of the three classes of antibiotics: macrolidelincosamide-streptogramin, other than methylases, 
which inactivate the antibiotic and usually act only on bone. These include hydrolases, which inactivate streptogramin B; esterases, which inactivate erythromycin; transferases which inactivate either lincomycin or streptogramin A, and phosphorylases which inactivate macrolides ${ }^{123}$. Another mechanism by which bacteria express macrolide resistance includes drug inactivation by an enzyme encoded by $m p h^{151}$.

\section{IVd. Resistance of oral species}

Ioannidou, et al. ${ }^{64}$ (2001) observed macrolide resistance to oral a-haemolytic streptococci in healthy Greek children. In 200 isolates, the prevalence of resistance to the two drugs was similar; the MIC90 for erythromycin was twice that of the value for clarithromycin. With $53 \%$ of isolates being resistant, $S$. oralis isolates showed the highest prevalence of resistance to erythromycin, after $S$. salivarius and S. sanguinis, with $48 \%$ and $44 \%$ of isolates resistant to this drug, respectively. A study by Sefton ${ }^{133}$ in 1999 demonstrated the presence of resistant species and the changes in the oral flora after administration of macrolides in patients with periodontal disease. Resistant streptococci increased significantly when compared with the placebo group, and remained at elevated levels for up to 3 months after treatment ${ }^{133}$.

Macrolide resistance in oral anaerobes frequently occurs together with tetracycline resistance ${ }^{151}$. Andres, et al. ${ }^{4}$ (1998) discusses the link between erythromycin and tetracycline resistance and $\beta$-lactamase production in Gram-negative anaerobes, concluding that they were associated with conjugative elements in oral Prevotella species. Sanai, et al. ${ }^{127}$ (2002) investigated the antibiotic resistance of $P$. gingivalis, $P$. intermedia and $P$. nigrescens. The action of erythromycin resistance genes alone and tetracycline resistance genes alone was similar in all of the strains. An equal proportion of $P$. intermedia isolates carried erm(F) alone or tet(Q) alone (21\% each, respectively). This has also been observed in other Prevotella species ${ }^{127}$. The effect on oral biofilms of a single tetracycline pulse demonstrated the relationship between tetracycline and erythromycin resistance. Of the isolates resistant to tetracycline, $67 \%$ were also resistant to erythromycin. A single pulse of tetracycline selected for erythromycin-resistant isolates, as shown by the increase in the proportion of such isolates in the biofilms from $5 \%$ to $28 \%^{115}$. The increasing prevalence of microorganisms resistant to erythromycin and the knowledge that erythromycin is considered the macrolide with the worst unwanted gastrointestinal effects have led to a decrease in the prescription of this drug both in medicine and in dentistry on the last decade ${ }^{10,134}$.

Haffajee, et al.51 (2008) observed ninety-two subjects with periodontitis. They were randomly allocated to one of four treatment groups receiving either SRP alone or combined with systemically administered azithromycin (500 mg once daily for 3 days), metronidazole ( $250 \mathrm{mg}$ tid for 14 days), or doxycycline (200 mg bid for 12 weeks). Subjects were clinically and microbiologically monitored at baseline (before therapy) and at 3, 6, and 12 months post-therapy. The proportion of resistant isolates was determined in saliva samples and in subgingival plaque samples at baseline and 12 months, and in two of these samples at time intervals of 2 weeks and 3 and 6 months. At the end of the study, the percentage of resistant isolates increased in plaque samples in all adjunctive treatment groups, peaking at the end of administration, but returned to pretreatment levels by 12 months.

\section{V- Metronidazole}

Metronidazole, a nitroimidazole compound, was discovered in the late 1950 s when researchers at Rhone-Poulenc Research Laboratories in France were trying to create a synthetic product from a Streptomyces spp called azomycin that would have activity against Trichomonas vaginalis. Metronidazole was initially found to be effective against certain protozoan pathogens: T. vaginalis, Giardia lambliae and Entamoeba histolytica. In a letter to the editor published in Lancet, Shinn ${ }^{136}$ (1962) reported on a patient with $T$. vaginalis and acute ulcerative gingivitis, who had a "double cure" after treatment with metronidazole for a week. This clinical observation led to studies that established metronidazole as an important antibiotic for anaerobic infection ${ }^{35}$. Since then, this compound has also played an important role in treating anaerobe related infection in the oral cavity ${ }^{84,111}$, abdomen ${ }^{38}$ and female genital tract ${ }^{65,85}$, among others. Recently, Helicobacter pylori has been strongly associated with gastritis and duodenal ulcers, and classic regimens for eradicating this pathogen have included metronidazole $39,44,141,147$.

Metronidazole can be considered a prodrug in the sense that it requires metabolic activation by sensitive organisms. The mechanism of action is believed to involve 4 phases: (1) entry into the bacterial cell; (2) reduction of the nitro group; (3) cytotoxic effect of the reduced product; and (4) release of end products that are inactive ${ }^{97}$. The formation of the redox intermediate intracellular metabolites is believed to be the key component of microorganism killing by metronidazole.

The intracellular targets for these intermediates could be the RNA, DNA or cellular proteins of the organisms ${ }^{38}$. Metabolic pathways of low redox potential, which are linked to ferredoxin or flavodoxin-like electron transport components, reduce metronidazole with great efficacy. Such 
pathways are characteristic of susceptible anaerobic protozoa and bacteria but are absent in aerobic and microaerophilic bacteria and also in host cells ${ }^{97}$. Therefore, all aerobic organisms are intrinsically resistant to these compounds.

Although metronidazole has been extensively used, acquired resistance to this drug has rarely been reported, especially for organisms that are considered classically susceptible, such as $T$. vaginalis and species of the Bacteroides fragilis group ${ }^{35,129}$. Decreased intracellular reduction and slower uptake of the drug are seen to be the main mechanism of resistance, but the genetic basis of these mechanisms is still unknown. Strains of $T$. vaginalis isolated from patients with refractory cases of trichomoniasis have been shown to contain decreased levels of ferredoxin, the protein that catalyzes reduction of metronidazole in these organisms. They also exhibit a corresponding reduction in the rate of ferredoxin gene transcription in comparison with drug-susceptible strains ${ }^{111}$. Resistance in $H$. pylori has been shown to emerge during antibiotic treatment ${ }^{43,58}$, and the prevalence of resistance can be associated with previous intake of metronidazole ${ }^{93}$. However the exact mechanism of metronidazole resistance for $\mathrm{H}$. pylori is not well understood. Moore, et al. ${ }^{95}$ (1995) investigated the uptake of metronidazole by sensitive and resistant strains of $H$. pylori. Both strains displayed rapid uptake of metronidazole, although the resistant strains accumulated the drug at a slower rate and in a smaller amount than the sensitive strain. Both slower uptake and decreased intracellular reduction of the drug were found in a strain of $B$. fragilis resistant to metronidazole ${ }^{152}$. Moreover, in 1978 , Ingham, and co-worker ${ }^{63}$ isolated a $B$. fragilis strain (NCTC 11295) with a level of resistance to metronidazole from a patient with Crohn's disease after a long-term metronidazole regimen. Since those first findings other resistant strains have been found in clinical specimens ${ }^{34}$; however they are still rare.

Four genes, $\operatorname{nim} A, \operatorname{nim} B, \operatorname{nim} C$ and $\operatorname{nim} D$, have been found which are able to confer moderate to high-level metronidazole resistance ${ }^{53,154,155}$. They are located on either the chromosome or a variety of plasmids ${ }^{140}$ and are transferable by conjugation or by transformation. All the nim genes have been found in Bacteroides species and they likely code for a 5-nitroimidazole reductase which enzymatically reduces the 5-nitroimidazole to a 5-amino derivative ${ }^{116}$.

\section{Va- Resistance of oral species}

Metronidazole seems to be effective against most Gram-negative anaerobic organisms found in the subgingival microbiota. Abu-Fanas, et al. $^{3}$ (1991) tested the susceptibility to different antibiotics of 61 Gram-negative rods isolated from deep periodontal pockets, including $P$. gingivalis, C. gracilis and F. nucleatum. Metronidazole was effective against all isolates except for a few strains of C. gracilis. A. actinomycetemcomitans, which is not an obligate anaerobe, is inherently resistant to metronidazole ${ }^{77}$. The combination of metronidazole and amoxicillin has been reported to be effective in the treatment of $A$. actinomycetmcomitansassociated periodontitis ${ }^{159,160}$. However, in an in vitro study, Muller, et al. ${ }^{96}$ (2002) found most strains of $A$. actinomycetemcomitans resistant to metronidazole while van Winkelhoff, et al. ${ }^{157}$ (2005) reported resistance of this bacterium to amoxicillin in Spanish patients.

Listgarten, et al. ${ }^{82}$ (1993) studied the pattern of antibiotic resistance in subgingival samples from patients with refractory periodontitis. Metronidazole resistance was recorded in $0-2 \%$ of anaerobic subgingival isolates, including Campylobacter rectus, $F$. nucleatum, $P$. intermedia and $P$. micra. Furthermore, biofilms offer bacterial resistance to antimicrobial therapy ${ }^{132,139}$. For this reason, taking into account the biofilm mode of growth of subgingival bacteria, Larsen, et al. ${ }^{76}$ (2002) evaluated the susceptibility of $P$. gingivalis to metronidazole. The minimal bactericidal concentration (MBC) for biofilm cells was higher than the MBC value for planktonic cells for all bacterial strains. Feres, et al. ${ }^{36}$ (2002), in a study with 20 chronic periodontitis patients, observed that the most prevalent resistant species in the metronidazole-treated group were: $A$. naes/undii 1, S. constellatus, Actinomyces naes/undii 2, S. mitis, S. oralis, Actinomyces odontolyticus and $S$. sanguinis. The mean percentage of resistant isolates increased during antibiotic administration and returned to baseline levels by 90 days post therapy. Ready, et al. ${ }^{114}$ (2003) did not find any child (4-5 years old) harboring metronidazole-resistant anaerobic bacteria. Similarly, Van Winkelhoff, et al. ${ }^{157}$ (2005) did not observe resistance of $P$. gingivalis strains to this antibiotic. In the same study, $F$. nucleatum was shown to be resistant to metronidazole. More recently, Rams, et al.112 (2011) conducted an in vitro analysis of bacterial resistance to metronidazole among recovered putative periodontal pathogens from subjects with severe periodontitis. $27 \%$ of the subjects harbored isolates resistant to $16 \mathrm{mg} / \mathrm{ml}$ of metronidazole, compared to $48.7 \%$ who harbored isolates resistant to $4 \mathrm{mg} / \mathrm{ml}$ of spiramycin and $62.2 \%$ to $8 \mathrm{mg} / \mathrm{mL}$ of amoxicillin. Due to the relatively lower rates of bacterial resistance to metronidazole and to its high activity against the Gram-negative anaerobic bacilli, which are associated with periodontal diseases, this seems to be a promising drug for treating periodontitis. 


\section{FINAL THOUGHTS}

The role of antibiotic prescription by the dental professionals in the selection of resistant bacteria is an area that has received relatively little attention $^{151}$. However, the literature suggests that antibiotic resistance in the periodontal microbiota has increased in the past decade ${ }^{5,57}$. In Dentistry, the most commonly prescribed antibiotics are the $\beta$-lactam drugs, which are commonly used to treat several oral infections as well as to prevent bacterial endocarditis or post-surgery infection. It is important to note that some of these applications, such as the use of amoxicillin right after implant placement, are not scientifically sustained. This kind of usage should be avoided in order to reduce the odds of developing bacterial resistance.

Whereas periodontitis is an infectious disease, systemic antimicrobial therapy has been suggested to treat this disorder. However, it should be noted that there are several specific features related to the etiology of periodontitis that may have important implications for the use of antimicrobial agents in the periodontal therapy. Therefore, extrapolating the results of antibiotic treatment for other human infections to periodontics is not suitable and should be avoided. For instance, subgingival bacteria growing in biofilms are more resistant to antimicrobial treatment than planktonic cultures, which are normally used for antimicrobial susceptibility testing. Biofilm is a difficult therapeutic target $^{139}$ that may demand higher antibiotics doses. Therefore, the strongest evidence on the use of antibiotics in the periodontal treatment should come from the in vivo studies. Fortunately, recent controlled clinical trials that have been conducted in an increasingly careful manner by different groups of investigators have helped to clear up several doubts about the proper use of systemic antibiotics in periodontology $16,17,22,23,45,51,52,94,138$. Overall these studies have showed that systemic antibiotics, especially the combination of metronidazole and amoxicillin are important adjuncts in the treatment of aggressive and chronic periodontitis. Some questions such as the ideal dose, duration and time of drug administration are still under investigation.

Finally, the dental professional should bear in mind that the non-specific or indiscriminate use of antibiotics may generate problems related to increase side-effects and bacterial resistance. However, when properly used, systemic antibiotics are very important tools in the treatment of periodontal diseases as well as of other oral infections.

\section{REFERENCES}

1- Abraham LJ, Berryman DI, Rood JI. Hybridization analysis of the class $\mathrm{P}$ tetracycline resistance determinant from the Clostridium perfrigens R-plasmid, pCW3. Plasmid. 1988;19:113-20.

2- Abu-Fanas SH, Drucker DB, Hull PS. Amoxicillin with clavulanic acid and tetracycline in periodontal therapy. J Dent. 1991;19:97-9. 3- Abu-Fanas SH, Drucker DB, Hull PS, Reeder JC, Ganguli LA. Identification and susceptibility to seven antimicrobial agents, of 61 gram-negative anaerobic rods from periodontal pockets. J Dent. 1991;19:46-50.

4- Andrés MT, Chung WO, Roberts MC, Fierro JF. Antimicrobial susceptibilities of Porphyromonas gingivalis, Prevotella intermedia, and Prevotella nigrescens spp. isolated in Spain. Antimicrob Agents Chemother. 1998;42:3022-3.

5- Ardila CM, Granada MI, Guzmán IC. Antibiotic resistance of subgingival species in chronic periodontitis patients. J Periodont Res. 2010;45:557-63.

6- Armitage GC. Comparison of the microbiological features of chronic and aggressive periodontitis. Periodontol 2000. 2010;53:70-88.

7- Arpin C, Canron MH, Noury P, Quentin C. Emergence of mefA and mefE genes in $\beta$-haemolytic streptococci and pneumococci in France. J Antimicrob Chemother. 1999;44:133-4.

8- Barza M, Brown RB, Shanks C, Gamble C, Weinstein L. Relation between lipophilicity and pharmacological behavior of minocycline, doxycycline, tetracycline and oxytetracycline in dogs. Antimicrob Agents Chemother. 1975;8:713-20.

9- Bernardo WL, Boriollo MFG, Gonçalves RB, Höfling JF. Staphylococcus aureus ampicillin-resistant from the odontological clinic environment. Rev Inst Med Trop Sao Paulo. 2005;47:19-24. 10- Bhatia N, Palta S, Arora K. Comparison of the effect of a single dose of erythromycin with pantoprazole on gastric content volume and acidity in elective general surgery patients. J Anaesthesiol Clin Pharmacol. 2011;27:195-8.

11- Bismuth R, Zilhao R, Sakamoto H, Guesdon JL, Courvalin P. Gene heterogeneity for tetracycline resistance in Staphylococcus spp. Antimicrob Agents Chemother. 1990;34:1611-4.

12- Blandizzi C, Malizia T, Lupetti A, Pesce D, Gabriele M, Giuca $M R$, et al. Periodontal tissue disposition of azithromycin in patients affected by chronic inflammatory periodontal diseases. J Periodontol. 1999;70:960-6.

13- Burdett V. Purification and characterization of Tet(M), a protein that renders ribosomes resistant to tetracycline. J Biol Chem. $1991 ; 266: 2872-7$.

14- Burdett V. Streptococcal tetracycline resistance mediated at the level of protein synthesis. J Bacteriol. 1986;165:564-9.

15- Butaye P, Cloeckaert A, Schwarz S. Mobile genes coding for efflux-mediated antimicrobial resistance in Gram-positive and Gram-negative bacteria. Int J Antimicrob Agents. 2003;22:205-10. 16- Carvalho LH, D'Avila GB, Leão A, Goncalves C, Haffajee $A D$, Socransky SS, et al. Scaling and root planing, systemic metronidazole and professional plaque removal in the treatment of chronic periodontitis in a Brazilian population. II. microbiological results. J Clin Periodontol. 2005;32:406-11.

17- Carvallho LH, D'Avila GB, Leão A, Haffajee AD, Socransky SS, Feres M. Scaling and root planing, systemic metronidazole and professional plaque removal in the treatment of chronic periodontitis in a Brazilian population. I. clinical results. J Clin Periodontol. 2004;31:1017-76.

18- Chambers HF, Sande MA. Antimicrobial agents. General considerations. In: Gilman AG, Rall TW, Nies AS, Taylor P. The pharmacological basis of therapeutics. New York: Pergamon Press; 1996. p. 1026-9.

19- Chan Y, Chan $\mathrm{CH}$. Antibiotic resistance of pathogenic bacteria from odontogenic infections in Taiwan. J Microbiol Immunol Infect. 2003;36:105-10.

20- Charpentier E, Gerbaud G, Courvalin P. Characterization of a new class of tetracycline-resistance gene tet(S) in Listeria monocytogenes BM4210. Gene. 1993;131:27-34. 
21- Ciancio SG, Slots J, Reynolds HS, Zambon JJ, McKenna JD. The effect of short-term administration of minocycline HCI on gingival inflammation and subgingival microflora. J Periodontol. 1982;53:557-61.

22- Cionca N, Giannopoulou C, Ugolotti G, Mombeli A. Amoxicilin and metronidazole as an adjunct to full-mouth scaling and root planning of chronic periodontitis. J Periodontol. 2009;80:364-71. 23- Cionca N, Giannopoulou C, Ugolotti G, Mombelli, A. Microbiologic testing and outcomes of full-mouth scaling and root planing with or without amoxicillin/metronidazole in chronic periodontitis. J Periodontol. 2010;81:15-23.

24- Cohen SP, McMurry LM, Hooper DC, Wolfson JS, Levy SB. Cross-resistance to fluoroquinolones in multiple-antibioticresistant (Mar) Escherichia coli selected by tetracycline or choloramphenicol: decreased drug accumulation associated with membrane changes in addition to OmpF reduction. Antimicrob Agents Chemother. 1989;33:1318-25.

25- Cohen SP, McMurry LM, Levy SB. marA locus causes decreases expression of OmpF porin in multiple-antibiotic-resistant (Mar) mutants of Escherichia coli. J Bacteriol. 1988;170:5416-22.

26- Collins JG, Offenbacher S, Arnold RR. Effects of a combination therapy to eliminate Porphyromonas gingivalis in refractory periodontitis. J Periodontol. 1993;64:998-1007.

27- Connel SR, Tracz DM, Nierhaus KH, Taylor DE. Ribosomal protection proteins and their mechanism of tetracycline resistance. Antimicrob Agents Chemother. 2003;47:3675-81.

28- Davies J. Inactivation of antibiotics and the dissemination of resistance genes. Science. 1994;264:375-82.

29- Day LE. Tetracycline inhibition of cell-free protein synthesis. II. Effect of the binding of tetracycline to the components of the system. J Bacteriol. 1966;92 197-203.

30- Deas ED, Mealey LB. Response of chronic and aggressive periodontitis to treatment. Periodontol 2000. 2010;53:154-66.

31- De Barbeyrac B, Dutilh B, Quentin C, Renaudin H, Bébéar C. Susceptibility of Bacteroides ureolyticus to antimicrobial agents and identification of a tetracycline resistance determinant related to tetM. J Antimicrob Chemother. 1991;27:721-31.

32- De Rossi E, Blokpoel MC, Cantoni R, Branzoni M, Riccardi G, Young DB, et al. Molecular cloning and functional analysis of a novel tetracycline resistance determinant, tet(V), from Mycobacterium smegmatis. Antimicrob Agents Chemother. 1998;42:1931-7.

33- Doyle D, McDowall KJ, Butler MJ, Hunter IS. Characterization of an oxytetracycline-resistance gene, otrA, of Streptomyces rimosus. Mol Microbiol. 1991;5:2923-33.

34- Dublanchet A, Caillon J, Emond JP, Chardon H, Drugeon $\mathrm{HD}$. Isolation of Bacteroides strains with reduced sensitivity to 5-nitroimidazoles. Eur J Clin Microbiol. 1986;5:346-7.

35- Falagas ME, Gorbach SL. Clindamycin and metronidazole. Med Clin North Am. 1995;79:845-67.

36- Feres M, Haffajee AD, Allard K, Som S, Goodson S, Socransky SS. Antibiotic resistance of subgingival species during and after antibiotic therapy. J Clin Periodontol. 2002;29:724-35.

37- Fiehn NE, Westergaard J. Doxycycline resistant bacteria in periodontally diseased individuals after systemic doxycycline therapy and in healthy individuals. Oral Microbiol Immunol. 1990;5:219-22.

38- Freeman CD, Klutman NE, Lamp KC. Metronidazole. A therapeutic review and update. Drugs. 1997;54:679-708.

39- Goh KL, Parasakthi N, Chuah SY, Toetsch M. Combination amoxicillin and metronidazole with famotidine in the eradication of Helicobacter pylori - a randomized, double-blind comparison of a three times daily and twice daily regimen. Eur J Gastroenterol Hepatol. 1997;9:1091-5.

40- Golub LM, Lee HM, Greenwald RA, Ryan ME, Sorsa T, Salo $T$, et al. A matrix metalloproteinase inhibitor reduces bone-type collagen degradation fragments and specific collagenases in gingival crevicular fluid during adult periodontitis. Inflamm Res. 1997;46:310-9.

41- Goodson JM. Antimicrobial strategies for treatment of periodontal diseases. Periodontol 2000. 1994;5:142-68.
42- Goodson JM, Tanner A. Antibiotic resistance of the subgingival microbiota following local tetracycline therapy. Oral Microbiol Immunol. 1992;7:113-7.

43- Goodwin CS, Marshall BJ, Blincow ED, Wilson DH, Blackbourn S, Phillips M. Prevention of nitroimidazole resistance in Campylobacter pylori by coadministration of colloidal bismuth subcitrate: clinical and in vitro studies. J Clin Pathol. 1988;41:207-10.

44- Graham DY, Hoffman J, el-Zimaity HM, Graham DP, Osato M. Twice a day quadruple therapy (bismuth subsalicylate, tetracycline, metronidazole plus lansoprazole) for treatment of Helicobacter pylori infection. Aliment Pharmacol Ther. 1997;11:935-8.

45- Guerrero A, Griffiths GS, Nibali L, Suvan J, Moles DR, Laurell L, et al. Adjuntive benefits of systemic amoxicillin and metronidazole in non-surgical treatment of generalized aggressive periodontitis: a randomized placebo-contolled clinical trial. J Clin Periodontol. 2005;32:1096-107.

46- Guiney DG, Bouic K. Detection of conjugal transfer systems in oral, black-pigmented Bacteroides spp. J Bacteriol. 1990;172:4957.

47- Guiney DG Jr, Hasegawa P, Davis CE. Expression in Escherichia coli of cryptic tetracycline resistance genes from Bacteroides $\mathrm{R}$ plasmids. Plasmid. 1989;11:248-52.

48- Hackbarth CJ, Chambers HF. Methicillin-resistant staphylococci: genetics and mechanisms of resistance. Antimicrob Agents Chemother. 1989;33:991-4.

49- Haffajee AD, Dibart S, Kent RL Jr, Socransky SS. Clinical and microbiological changes associated with the use of 4 adjunctive systemically administered agents in the treatment of periodontal infections. J Clin Periodontol. 1995;22:618-27.

50- Haffajee AD, Dibart S, Kent RL Jr, Socransky SS. Factor associated with different responses to periodontal therapy. J Clin Periodontol. 1995;22:628-36.

51- Haffajee AD, Patel M, Socransky SS. Microbiological changes associated with four different periodontal therapies for the treatment of chronic periodontitis. Oral Microbiol Immunol. 2008;23:148-57.

52- Haffajee AD, Torresyap G, Socransky SS. Clinical changes following four different periodontal therapies for the treatment of chronic periodontitis: 1-year results. J Clin Periodontol. 2007;34:243-53.

53- Haggoud A, Reysset G, Azeddoug H, Sebald M. Nucleotide sequence analysis of two 5-nitromidazole resistance determinants from Bacteroides strains and of a new insertion sequence upstream of the two genes. Antimicrob Agents Chemother. 1994;38:104751.

54- Hakenbeck R, Coyette J. Resistant penicillin-binding proteins. Cell Mol Life Sci. 1998;54:332-40.

55- Handal T, Olsen I, Walker CB, Caugant DA. $\beta$-lactamase protection and antimicrobial susceptibility of subgingival bacteria from refractory periodontitis. Oral Microbiol Immunol. 2004;19:303-8.

56- Hansen LM, McMurry LM, Levy SB, Hirsh DC. A new tetracycline resistance determinant, Tet $\mathrm{H}$, from Pasteurella multocida specifying active efflux of tetracycline. Antimicrob Agents Chemother. 1993;37:2699-705.

57- Herrera D, Alonso B, León R, Roldán S, Sanz M. Antimicrobial therapy in periodontitis: the use of systemic antimicrobials against the subgingival biofilm. J Clin Periodontol. 2008;35(Suppl. 8):4566.

58- Hirschl AM, Hentschel E, Schütze $K$, Nemec $H$, Pötzi $R$, Gangl A, et al. The efficacy of antimicrobial treatment in Campylobacter pylori - associated gastrit and duodenal ulcer. Scand J Gastroenterol Suppl. 1988;142:76-81.

59- Hoepelman IM, Schneider MM. Azithromycin: the first of the tissue-selective azalides. Int J Antimicrob Agents. 1995;5(3):14567.

60- Horn R, Lavallée J, Robson HG. Susceptibilities of members of the Bacteroides fragilis group to 11 antimicrobial agents. Antimicrob Agents Chemother. 1992;36;2051-3. 
61- Hoshino T, Ikeda T, Tomizuka N, Furukawa K. Nucleotide sequence of the tetracycline resistance gene of PTHT15, a thermophilic Bacillus plasmid: comparison with staphylococcal TcR controls. Gene. 1985;37:131-8.

62- Ince D, Hooper DC. Quinolone resistance due to reduced target enzyme expression. J Bacteriol. 2003;185:6883-92.

63- Ingham HR, Eaton S, Venables CW, Adams PC. Bacteroides fragilis resistant to metronidazole after long-term therapy. Lancet. $1978 ; 1: 214$.

64- Ioannidou S, Tassios PT, Kotsovili-Tseleni A. Foustoukou M, Legakis NJ, Vatopoulos A. Antibiotic resistance rates and macrolide resistance phenotypes of viridians group streptococci from the oropharynx of healthy Greek children. Int J Antimicrob Agents. 2001;17:195-201.

65- Joesoef MR, Schmid GP. Bacterial vaginosis: review of treatment options and potential clinical indications for therapy. Clin Infect Dis. 1995;20:S72-9.

66- Jorgensen JH, Doern GV, Maher LA, Howell AW, Redding JS. Antimicrobial resistance among respiratory isolates of Haemophilus influenza, Moraxella catarrhalis, and Streptococcus pneumonia in the United States. Antimicrob Agents Chemother. 1990;34:207580.

67- Kaatz GW. Bacterial efflux pump inhibition. Curr Opin Investig Drugs. 2005;6:191-8.

68- Kapusnik-Uner JE, Sande MA, Chambers HF. Antimicrobial agents: penicillins, cephalosporins, and other beta-lactam antibiotics. In: Gilman AG, Hardman JG, Limbird LE. The pharmacological basis of therapeutic. New York: Pergamon Press; 1996. p. 1123-53.

69- Kim SM, Kim HC, Lee SW. Characterization of antibiotic resistance determinants in oral biofilms. J Microb. 2011;49:594602.

70- Kinder SA, Holt SC, Korman KS. Penicillin resistance in the subgingival microbiota associated with adult periodontitis. J Clin Microbiol. 1986;23:1127-33.

71- King A, Bathgate T, Phillips I. Erythromycin susceptibility of viridans streptococci from the normal throat flora of patients treated with azithromycin or clarithromycin. Clin Microbiol Infect. 2002;8:85-92.

72- Kornman KS, Karl EH. The effect of long-term low-dose tetracycline therapy on the subgingival microflora in refractory adult periodontitis. J Periodontol. 1982;53:604-10.

73- Laatsch LJ. Hohenfeldt PR, Kos WL. Antibiotic susceptibility of black-pigmented Bacteroides isolates from the human oral cavity. Antimicrob Agents Chemother. 1982;22:698-700.

74- Lacroix JM, Walker CB. Detection and incidence of the tetracycline resistance determinant tet(M) in the microflora associated with adult periodontitis. J Periodontol. 1995;66:102-8. 75- Lacroix JM, Walker CB. Detection and prevalence of the tetracycline resistance determinant Tet $\mathrm{Q}$ in the microbiota associated with adult periodontitis. Oral Microbiol Immunol. 1996; $11: 282-8$.

76- Larsen T. Susceptibility of Porphyromonas gingivalis in biofilms to amoxicillin, doxycycline and metronidazole. Oral Microbiol Immunol. 2002; 17:267-71.

77- Larsen T, Fiehn NE. Development of resistance to metronidazole and minocycline in vitro. J Clin Periodontol. 1997; 24: 254-259. 78- LeBlanc DJ, Lee LN, Titmas BM, Smith CJ, Tenover FC. Nucleotide sequence analysis of tetracycline resistance gene tetO from Streptococcus mutans DL5. J Bacteriol. 1988;170:3618-26. 79- Leclercq R. Mechanisms of resistance to macrolides and lincosamides: nature of the resistance elements and their clinical implications. Clin Infect Dis. 2002;34:482-92.

80- Levy SB. Evolution and spread of tetracycline resistance determinants. J Antimicrob Chemother. 1989;24:1-3.

81- Li XZ, Nikaido H. Efflux-mediated drug resistance in bacteria. Drugs. $2004 ; 64: 159-204$.
82- Listgarten MA, Lai CH, Young V. Microbial composition and pattern of antibiotic resistance in subgingival microbial samples from patients with refractory periodontitis. J Periodontol. 1993;64:155-61.

83- Loberto JCS, Martins CAP, Santos SSF, Cortelli JR, Jorge AOC. Staphylococcus spp. in the oral cavity and periodontal pockets of chronic periodontitis patients. Braz J Microb. 2004;35:64-8. 84- Loesche WJ, Syed SA, Laughon BE, Stoll J. The bacteriology of acute necrotizing ulcerative gingivitis. J Periodontol. 1982;53:22330.

85- Lugo-Miro VI, Green M, Mazur L. Comparison of different metronidazole therapeutic regiments for bacterial vaginosis. A meta-analysis. JAMA. 1992;268:92-5.

86- Maestre JR, Bascones A, Sánchez P, Matesanz P, Aguilar L, Giménez $M J$, et al. Odontogenic bacteria in periodontal disease and resistance patterns to common antibiotics used as treatment and prophylaxis in odontology in Spain. Rev Esp Quimioter. 2007;20:61-7.

87- Magnusson I, Low SB, McArthur WP, Marks RG, Walker CB, Maruniak J, et al. Treatment of subjects with refractory periodontal disease. J Clin Periodontol. 1994;21:628-37.

88- Magnusson I, Marks RG, Clark WB, Walker CB, Low SB, McArthur WP. Clinical, microbiological and immunological characteristics of subjects with "refractory" periodontal disease. J Clin Periodontol. 1991;18:291-9.

89- Mandell GL, Phillips RW. Antimicrobial agents: penicillins, cephalosporins, and other beta-lactam antibiotics. In: Gilman AG, Hardman JG, Limbird LE. The pharmacological basis of therapeutic. New York: Pergamon Press; 1996. p. 1073-101.

90- Maxwell IH. Studies of the binding of thetracycline to ribosomes in vitro. Mol Pharmacol. 1968;4:25-37.

91- McMurry L, Petrucci RE Jr, Levy SB. Active efflux of tetracycline encoded by four genetically different tetracycline resistance determinants in Escherichia coli. Proc Natl Acad Sci USA. $1980 ; 77: 3974-7$.

92- McMurry LM, Park BH, Burdett V, Levy SB. Energy-dependent efflux mediated by class $L$ (tetL) tetracycline resistance determinant from streptococci. Antimicrob Agents Chemother. 1987;31:1648-50.

93- Mégraud F. Antibiotic resistance in Helicobacter pylori infection. Br Med Bull. 1998;54:207-16.

94- Mestnik MJ, Feres M, Figueiredo LC, Duarte PM, Lira EAG, Faveri $M$. Short-term benefits of the adjunctive use of metronidazole plus amoxicillin in the microbial profile and in the clinical parameters of subjects with generalized aggressive periodontitis. J Clin Periodontol. 2010;37:353-65.

95- Moore RA, Beckthold B, Bryan LE. Metronidazole uptake in Helicobacter pylori. Can J Microbiol. 1995;41:746-9.

96- Müller HP, Holderrieth $S$, Burkhardt $U$, Höffler U. In vitro antimicrobial susceptibility of oral strains of Actinobacillus actinomycetencomitans to seven antibiotics. J Clin Periodontol. 2002;29:736-42.

97- Müller M. Mode of action of metronidazole on anaerobic bacteria and protozoa. Surgery. 1983;93:165-71.

98- Nakae T. Outer-membrane permeability of bacteria. Crit Rev Microbiol. 1986;13:1-62.

99- Nesin M, Svec P, Lupski JR, Godson GN, Kreiswirth B, Kornblum $J$, et al. Cloning and nucleotide sequence of a chromosomally encoded tetracycline resistance determinant, tet $A(M)$, from a pathogenic, methicillin-resistance strain of Staphylococcus aureus. Antimicrob Agents Chemother. 1990;34:2273-6.

100- Nikaido H. Multidrug resistance in bacteria. Annu Rev Biochem. 2009;78:119-46.

101- Nikaido H. Prevention of drug access to bacterial targets: permeabitity barriers and active aafflux. Science. 1994;264:382-8. 102- Nikolich MP, Shoemaker NB, Salyers AA. A Bacteroides tetracycline resistance gene represents a new class of ribosome protection tetracycline resistance. Antimicrob Agents Chemother. 1992;36:1005-12. 
103- Nyfors S, Könönen E, Syrjänen R, Komulainen E, JousimiesSomer $\mathrm{H}$. Emergence of penicillin resistance among Fusobacterium nucleatum populations of commensal oral flora during early childhood. J Antimicrob Chemother. 2003;51:107-12.

104- Olsvik B, Flynn MJ, Tenover FC, Slots J, Olsen I. Tetracycline resistance in Prevotella isolates from periodontally diseased patients in due to the tet( $Q)$ gene. Oral Microbiol Immunol. 1996; $11: 304-8$

105- Olsvik B, Hansen BF, Tenover FC, Olsen I. Tetracyclineresistant micro-organisms recovered from patients with refractory periodontal disease. J Clin Periodontol. 1995;22:391-6.

106- Osvik B, Olsen I, Tenover FC. Detection of tet(M) and tet $(\mathrm{O})$ using the polymerase chain reaction in bacteria isolated from patients with periodontal disease. Oral Microbiol Immunol. 1995;10:87-92.

107- Olsvik B, Olsen I, Tenover FC. The tet( $Q)$ gene in bacteria isolated from patients with refractory periodontal disease. Oral Microbiol Immunol. 1994;9:251-5.

108- Olsvik B, Tenover FC, Olsen I, Rasheed JK. Three subtypes of tet(M) gene identified in bacterial isolates from periodontal pockets. Oral Microbiol Immunol. 1996;11:299-303.

109- Pato ML. Tetracycline inhibits propagation of deoxyribonucleic acid replication and alters membrane properties. Antimicrob Agents Chemother. 1977;11:318-323.

110- Poulsen SM, Kofoed C, Vester B. Inhibition of the ribosomal peptidyl transferase reaction by the mycarose moiety of the antibiotics carbomycin, spiramycin and tylosin. J Mol Biol. 2000;304:471-81.

111- Quon DV, d'Oliveira CE, Johnson PJ. Reduced transcription of the ferredoxin gene in metronidazole-resistant Trichomonas vaginalis. Proc Natl Acad Sci U.S.A. 1992;89:4402-6.

112- Rams TE, Dujardin S, Sautter JD, Degener JE, Van Winkelhoff AJ. Spiramycin resistance in human periodontitis microbiota. Anaerobe. 2011;17:201-5.

113- Ramos JL, Martínez-Bueno M, Molina-Henares AJ, Terán W, Watanabe $K$, Zhang $X$, et al. The TetR family of transcriptional repressors. Microbiol Mol Biol Ver. 2005;69:326-56.

114- Ready D, Bedi R, Spratt DA, Mullany P, Wilson M. Prevalence, proportions, and identities of antibiotic-resistant bacteria in the oral microflora of healthy children. Microb Drugs Resist. 2003;9:367-72.

115- Ready D, Roberts AP, Pratten J. Spratt DA, Wilson M, Mullany P. Composition and antibiotic resistance profile of microcosm dental plaques before and after exposure to tetracycline. J Antimicrob Chemother. 2002;49:769-75.

116- Reysset G. Genetics of 5-nitroimidazole resistance in Bacteroides species. Anaerobe. 1996;2:59-69.

117- Roberts MC. Antibiotic toxicity, interactions and resistance development. Periodontol 2000. 2002;28:280-97.

118- Roberts MC. Tetracycline resistance determinants: mechanisms of action, regulation of expression, genetic mobility, and distribution. FEMS Microbiol Rev. 1996;19:1-24.

119- Roberts MC, Hillier SL. Genetic basis of tetracycline resistance in urogenital bacteria. Antimicrob Agents Chemother. 1990;34:261-4.

120- Roberts MC, Lansciardi J. Transferable Tet M in Fusobacterium nucleatum. Antimicrob Agents Chemother. 1990;34:1836-8.

121- Roberts MC, Moncla BJ. Tetracycline resistance and TetM in oral anaerobic bacteria and Neisseria perflava-N. sicca. Antimicrob Agents Chemother. 1988;32:1271-3.

122- Roberts MC, Pang YJ, Spencer RC, Winstanley TG, Brown BA, Wallace RJ Jr. Tetracycline resistance in Moraxella (Branhamella) catarrhalis: demonstration of two clonal outbreaks by using pulsed-field gel electrophoresis. Antimicrob Agents Chemother. 1991;35:2453-5.

123- Roberts MC, Sutcliffe J, Courvalin P, Jensen LB, Rood J, Seppala H. Nomenclature for macrolide and macrolidelincosamide-streptogramin B resistance determinants. Antimicrob Agents Chemother. 1999;43:2823-30.
124- Robicsek A, Strahilevitz J, Jacoby GA, Macielag M, Abbanat $D$, Park $\mathrm{CH}$, et al. Fluoroquinolone-modifying enzyme: a new adaptation of a common aminoglycoside acetyltransferase. Nat Med. $2006 ; 12: 83-8$.

125- Rodrigues RM, Gonçalves C, Souto R, Feres-Filho EJ, Uzeda $M$, Colombo AP. Antibiotic resistance profile of the subgingival microbiota following systemic or local tetracycline therapy. J Clin Periodontol. 2004;31:420-7.

126- Salyers AA, Speer BS, Shoemaker NB. New perspectives in tetracycline resistance. Mol Microbiol. 1990;4:151-6.

127- Sanai Y, Persson GR, Starr JR, Luis HS, Bernardo M, Leitao $\mathrm{J}$, et al. Presence and antibiotic resistance of Porphyromonas gingivalis, Prevotella intermedia, and Prevotella nigrescens in children. J Clin Periodontol. 2002;29:929-34.

128- Sanders CC, Sanders WE Jr, Goering RV, Werner V. Selection of multiple antibiotic resistance by quinolones, beta-lactams, and aminoglycosides with special reference to cross-resistance between unrelated drug classes. Antimicrob Agents Chemother. 1984;26:797-801.

129- Scher KS. Emergence of antibiotic resistant strains of Bacteroides fragilis. Surg Gynecol Obstet. 1988;167:175-9.

130- Schnappinger D, Hillen W. Tetracyclines: antibiotic action, uptake, and resistance mechanisms. Arch Microbiol. 1996;165:359-69.

131- Sedgley CM, Lennan SL, Clewell DB. Prevalence, phenotype and genotype of oral enterococci. Oral Microbiol Immunol. 2004;19:95-101.

132- Sedlacek MJ, Walker C. Antibiotic resistance in an in vitro subgingival biofilm model. Oral Microbiol Immunol. 2007;22:3339.

133- Sefton AM. Macrolides and changes in the oral flora. Inter J Antimicrob Agents. 1999;11:S23-9;S31-2.

134- Seymour RA, Hogg SD. Antibiotics and chemoprophylaxis. Periodontol 2000. 2008;46:80-108.

135- Sharma R, Sharma CL, Kapoor B. Antibacterial resistance: current problems and possible solutions. Indian J Med Sci. 2005;59:120-9.

136- Shinn D. Metronidazole in acute ulceration gingivitis. Lancet. 1962:1:1191.

137- Shoemaker NB, Barber RD, Salyers AA. Cloning and characterization of a Bacteroides conjugal tetracyclineerythromycin resistance element by using a shuttle cosmid vector. J Bacteriol. 1989;171:1294-302.

138- Silva MP, Feres M, Siroto TA, Soares GM, Mendes JAV, Faveri $M$, et al. Clinical and microbiological benefits of metronidazole alone or with amoxicillin as adjuncts in the treatment of chronic periodontitis: a randomized placebo-controlled clinical trial. J Clin Periodontol. 2011;38:828-37.

139- Socransky SS, Haffajee AD. Dental biofilms: difficult therapeutic targets. Periodontol 2000. 2002;28:12-55.

140- Sóki J, Gal M, Brazier JS, Rotimi VO, Urbán E, Nagy E, et al. Molecular investigation of genetic elements contributing to metronidazole resistance in Bacteroides strain. J Antimicrob Chemother. 2006;57:212-20.

141- Soll AH. Consensus conference. Medical treatment of peptic ulcer disease. Practice guidelines. Practice Parameters Committee of the American College of Gastroenterology. JAMA. 1996;275:622-9.

142- Speer BS, Shoemaker NB, Salyers AA. Bacterial resistance to tetracycline: mechanisms, transfer, and clinical significance. Clin Microbiol Rev. 1992;5:387-99.

143- Spratt BG. Biochemical and genetical approaches to the mechanism of action of penicillin. Philos Trans R Soc Lond B Biol Sci. 1980;289:273-83.

144- Spratt BG. The mechanism of action of penicillin. Sci Prog. 1978;65:101-28.

145- Spratt BG. Resistance to antibiotics mediated by target alterations. Science. 1994;264:388-93. 
146- Stabholz A, Kettering J, Aprecio R, Zimmerman G, Baker PJ, Wikesjö UM. Antimicrobial properties of human dentin impregnated with tetracycline $\mathrm{HCl}$ or chlorhexidine. An in vitro study. J Clin Periodontal. 1993;20:557-62.

147- Stupnicki T, Taufer M, Denk H, Ratschek M, Spath P, Graf $\mathrm{K}$. Triple therapy with sucralfate, amoxicillin and metronidazole for healing duodenal ulcer and eradicating Helicobacter pylori infection. Aliment Pharmacol Ther. 1996;10:193-7.

148- Suarez G, Nathans D. Inhibition of aminoacyl tRNA binding to ribosomes by tetracycline. Biochem Biophys Res Commun. 1965; 18:743.

149- Sutter VL, Finegold SM. Susceptibility of anaerobic bacteria to 23 antimicrobial agents. Antimicrob Agents Chemother. $1976 ; 10: 736-52$.

150- Sutter VL, Jones MJ, Ghoneim AT. Antimicrobial susceptibilities of bacteria associated with periodontal disease. Antimicrob Agents Chemother. 1983;23:483-6.

151- Sweeney LC, Dave J, Chambers PA, Heritage J. Antibiotic resistance in general dental practice - a cause for concern? J Antimicrobial Chemotherapy. 2004;53:567-76.

152- Tally FP, Snydman D, Shimmel M. Mechanisms of antimicrobial resistance of Bacteroides fragilis in Phillips I, Collier J (editors): Metronidazole: Proceedings of the Second International Symposium on Anaerobic Infections. London: Academic Press; 1979.

153- Tauch A, Pühler A, Kalinowski J, Thierbach G. TetZ, a new tetracycline resistance determinant discovered in gram-positive bacteria, shows high homology to gram-negative regulated efflux systems. Plasmid. 2000;44:285-91.

154- Trinh S, Haggoud A, Reysset G, Sebald M. Plasmids pIP419 and pIP421 from Bacteroides: 5-nitroimidazole resistance genes and their upstream insertion sequence elements. Microbiology. 1995; 141:927-35.

155- Trinh S, Reysset G. Identification and DNA sequence of the mobilization region of the 5-nitroimidazole resistance plasmid pIP421 from Bacteroides fragilis. J Bacteriol. 1997;179:4071-4. 156- Vachon V, Lyew DJ, Coulton JW. Transmembrane permeability channels across the outer membrane of Haemophilus influenza type b. J Bacteriol. 1985;162:918-24.

157- Van Winkelhoff AJ, Herrera D, Oteo A, Sanz M. Antimicrobial profiles of periodontal pathogens isolated from periodontitis patients in The Netherlands and Spain. J Clin Periodontol. 2005;32:891-8.

158- Van Winkelhoff AJ, Herrera Gonzales D, Winkel EG, DellemijnKippuw N, Vandenbroucke-Grauls CM, Sanz M. Antimicrobial resistance in the subgingival microflora in patients with adult periodontitis. A comparison between the Netherlands and Spain. J Clin Periodontol. 2000;27:79-86.
159- Van Winkelhoff AJ, Rodenburg JP, Goené RJ, Abbas F, Winkel EG, De Graaff J. Metronidazole plus amoxycillin in the treatment of Actinobacillus actinomycetemcomitans associated periodontitis. J Clin Periodontol. 1989;16:128-31.

160- Van Winkelhoff AJ, Tijhof CJ, De Graaff J. Microbiological and clinical results of metronidazole plus amoxicillin therapy in Actinobacillus actinomycetemcomitans associated periodontitis. J Periodontol. 1992;63:52-7.

161- Van Winkelhoff AJ, Winkel EG, Barendregt D, DellemijnKippuw N, Stijne A, Van Der Velder. Beta-Lactamase producing bacteria in adult periodontitis. J Clin Periodontol. 1997;24:538-43. 162- Villideu A, Diaz-Torres ML, Hunt N, McNab R, Spratt DA, Mullany. Prevalence of tetracycline resistance genes in oral bacteria. Antimicrob Agents Chemother. 2003;47:878-82.

163- Walker $\mathrm{CB}$. The acquisition of antimicrobial resistance in the periodontal microflora. Periodontol 2000. 1996;10:79-88.

164- Walker CB. Selected antimicrobial agents: mechanisms of action, side effects and drug interactions. Periodontol 2000. $1996 ; 10: 12-28$.

165- Walker CB, Karpinia K, Baehni P. Chemotherapeutics: antibiotics and other antimicrobials. Periodontol 2000. 2004;36:146-65.

166- Walsh C. Where will new antibiotics come from? Nat Rev Microbiol. 2003;1:65-70.

167- Whittle G, Whitehead TR, Hamburger N, Shoemaker NB, Cotta MA, Salyers AA. Identification of a new ribosomal protective type of tetracycline resistance gene, tet(36), from swine manure pits. Appl Environ Microbiol. 2003;69:4151-8.

168- Williams BL, Osterberg SK, Jorgensen J. Subgingival microflora of periodontal patients on tetracycline therapy. J Clin Periodontol. 1979;6:210-21.

169- Yocum RR, Rasmussen JR, Strominger JL. The mechanism of action of penicillin. Penicillin acylates the active site of Bacillus stearothermophilus D-alanine carboxypeptidase. J Biol Chem. 1980;255:3977-86.

170- Yonath A. Ribosomal crystallography: peptide bond formation, chaperone assistance and antibiotics activity. Mol Cells. $2005 ; 20: 1-16$.

171- Zihao R, Papadopoulou B, Courvalin P. Occurrence of the Campylobacter resistance gene tetO in Enterococcus and Streptococcus spp. Antimicrob Agents Chemother. 1988;32:17936.

172- Zuckerman JM, Qamar F, Bono BR. Review of macrolides (azithromycin, clarithromycin), ketolids (telithromycin) and glycylcyclines (tigecycline). Med Clin North Am. 2011;95;761-91. 